\title{
When consumers love their brands: Exploring the consumers' emotional characteristics on purchasing Apple mobile devices
}

\author{
Hosseinali Aziziha ${ }^{\mathrm{a}}$, Ashkan Faraji ${ }^{\mathrm{a}}$, Milad Isakhani Zakaria ${ }^{\mathrm{b}}$, Mahsan Hajirasouliha ${ }^{\mathrm{a}}$ and Seyed \\ Shahab Mousavi ${ }^{\mathbf{a}^{*}}$
}

${ }^{a}$ Department of Management and Accounting, South Branch, Islamic Azad University, Tehran, Iran ${ }^{b}$ Department of Management and Accounting, University of Tehran, Tehran, Iran

\section{CHRON I C LE A B T T A C T}

\begin{tabular}{l}
\hline Article history: \\
Received October 28, 2013 \\
Received in revised format \\
25 November 2013 \\
Accepted 19 January 2014 \\
Available online \\
January 212014 \\
\hline Keywords: \\
Emotional intelligence \\
Love brand \\
Apple mobile device
\end{tabular}

\section{Introduction}

During the past few years, Apple has become as one of the most successful firms for offering mobile phone in the world and it competes with its competitors through different types of products and services (Keller, 2001; Park et al., 2006). Despite the fact that there is a big difference between Apple mobile devices and similar products, Apple has been able to gain a good market share and becomes a giant provider of mobile devices. These days, when Apple offers a new model of its products, there are people who stay in queue for several hours to be the first who purchase and use such products and services. Many people are concerned to find out about the real motivation among people in Apple products. Albert et al. (2008) extracted eleven dimensions that could emerge to describe people's

*Corresponding author.

E-mail addresses: moosavi.shahab@ymail.com (S. S. Mousavi) 
feeling of love and the special type of relationships they have with the brands they love. Carroll and Ahuvia (2006) explained that satisfied consumers' love was bigger for brands in product categories perceived as more hedonic and for brands that offer more in terms of symbolic benefits. Brand love, in turn, was linked to higher levels of brand loyalty and positive word-of-mouth and the investigation indicated that satisfied consumers tend to be less loyal to brands in more hedonic product categories and to engage in more positive word-of-mouth about self-expressive brands. Hwang and Kandampully (2012) investigated the role of emotional aspects in younger consumer-brand relationships. They tried to study the roles of three emotional factors including self-concept connection, emotional attachment, and brand love in the context of younger consumer-luxury brand relationships.

According to Ahluwalia et al. (2000), even though negative data about brands and firms may widely prevalent in the marketplace, except for case studies, there are only few studies on how consumers process negative data about the brands they like and apply and Ahluwalia et al. (2000) tried to bridge this gap. The results of the first and second studies provided a theoretical framework for understanding how people process negative data in the marketplace. They detected commitment of the consumer toward the brand as a moderator of negative information impacts. They also applied this theoretical framework to derive and examine response strategies that companies may apply to counter negative publicity for consumers who were high and low in commitment toward the brand.

\section{The proposed study}

This paper presents an empirical study to investigate the effect of emotional intelligence on customer's adoption of Apple mobile devices. The study considers four emotional dimensions including emotional management, self-adjustment, empathy, social skills and self-motivation using a standard questionnaire developed by Goleman (2006). The study also uses another questionnaire, which measures love brand and both questionnaires are designed in Likert scale (Aaker, 1996; Mayer et al., 1999). The sample size is selected from people who are using Apple products in city of Tehran, Iran as follows,

$N=Z_{\alpha / 2}^{2} \frac{p \times q}{e^{2}}$,

where $N$ is the sample size, $p=1-q$ represents the probability, $z_{\alpha / 2}$ is CDF of normal distribution and finally $\varepsilon$ is the error term. For our study we assume $p=0.5, z_{\alpha / 2}=1.96$ and $e=0.05$, the number of sample size is calculated as $N=384$. The proposed study distributed 400 questionnaires and collected 384 properly filled ones. Cronbach alphas for emotional intelligence and love brand are measured as 0.78 and 0.83 , respectively, which are above the acceptance level of 0.70 . Therefore, we can confirm the validity of both questionnaires. Fig. 1 demonstrates the results of the proposed study.

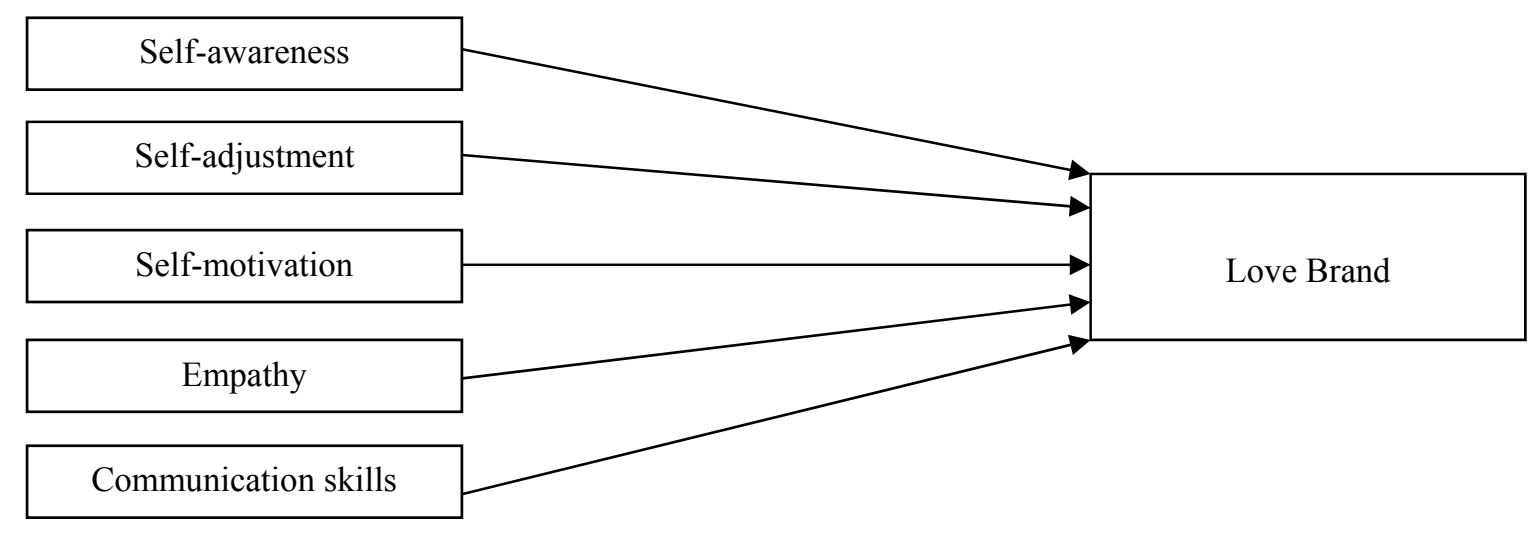

Fig. 1. The proposed study 


\subsection{Personal characteristics}

In our survey, $43.5 \%$ of the participants were female and $56.5 \%$ of them were male. Fig. 1 demonstrates the summary of the participants' characteristics.

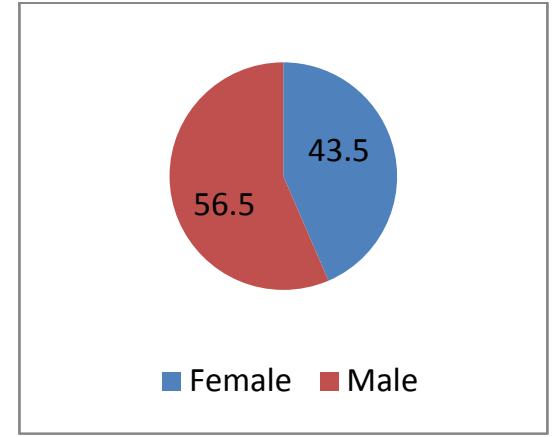

Gender

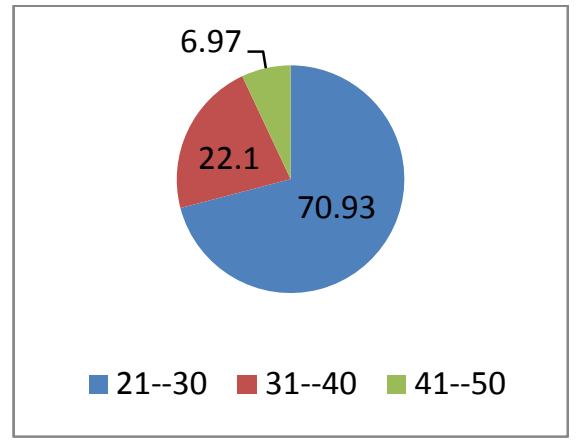

Age

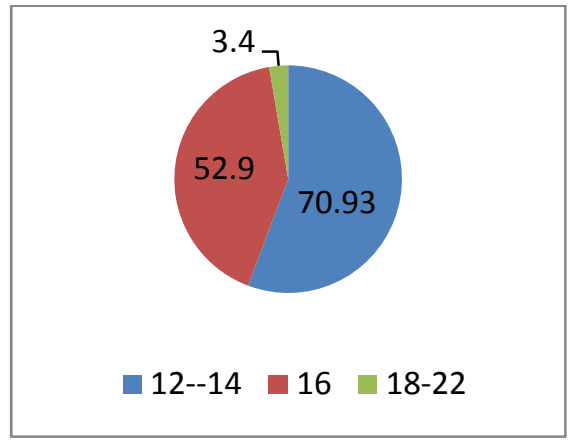

Years of education

Fig. 1. Personal characteristics of the participants

According to Fig. 1, most participants we middle aged people and have some educational backgrounds. The proposed study considers the following five hypotheses,

1. There is a positive and meaningful relationship between self-awareness and brand.

2. There is a positive and meaningful relationship between self-adjustment and brand.

3. There is a positive and meaningful relationship between self-motivation and brand.

4. There is a positive and meaningful relationship between empathy and brand.

5. There is a positive and meaningful relationship between social skills and brand.

We have performed normality test using Kolmogorov-Smirnov test where the null hypothesis states that all data are normally distributed and the alternative hypothesis states that data are not normally distributed. Therefore, we use Spearman correlation test to examine different hypotheses. Table 1 summarizes the results of our survey.

\section{Table 1}

The summary of testing various hypotheses based Spearman correlation test

\begin{tabular}{lccc}
\hline Hypothesis & $\mathrm{r}$ & sig & Result \\
\hline Self-awareness and brand & .472 & .002 & Confirmed \\
Self-adjustment and brand & .359 & .004 & Confirmed \\
Self-motivation and brand & .306 & .011 & Confirmed \\
Empathy and brand & .228 & .007 & Confirmed \\
Social skills and brand & .195 & .000 & Confirmed \\
\hline $\mathrm{P}<0.05$ & & &
\end{tabular}

As we can observe from the results of Table 1, the implementation of Spearman correlation test confirms all hypotheses of the survey. Next, we apply stepwise regression model to study the relationship between brand and emotional intelligence. Table 2 shows details of our findings.

Table 2

The summary of regression analysis

\begin{tabular}{cccccc}
\hline Variable & $\beta$ & Error & Standard $\beta$ & T-value & Sig. \\
\hline Intercept & 53.286 & 5.352 & & 14.529 & .000 \\
Self-awareness & .561 & .308 & .391 & 2.324 & .006 \\
Self-motivation & .523 & .270 & .363 & 2.291 & .003 \\
Empathy & .497 & .221 & .317 & 2.157 & .001 \\
\hline
\end{tabular}


As we can observe from the results of Table 2, brand is a function of self-awareness, self-motivation and empathy. In our study, self-awareness has the highest impact on emotional intelligence followed by self-motivation and empathy.

\section{Conclusion}

In this paper, we have presented an empirical investigation on the impact of different emotional intelligence on brand. The proposed study has been applied among people who loved Apple products and services. The study has been accomplished among residence of city of Tehran, Iran whose people use mobile devises for their daily activities. The results of this study have confirmed that selfawareness is the most important component of emotional intelligence, which creates sufficient motivation to purchase Apple products. In addition, it appears that self-motivation is another important factor influencing people to become interested in Apple mobile services. Finally, empathy is considered the last important item, which is influencing brand among Apple followers.

\section{Acknowledgement}

The authors would like to thank the anonymous referees for comments on earlier version of this paper.

\section{References}

Aaker, D.A. (1996). Building Strong Brands. The Free Press, New York, NY.

Ahluwalia, R., Burnkrant, R. E., \& Unnava, H. R. (2000). Consumer response to negative publicity: The moderating role of commitment. Journal of Marketing Research, 37(2), 203-214.

Albert, N., Merunka, D., \& Valette-Florence, P. (2008). When consumers love their brands: Exploring the concept and its dimensions. Journal of Business Research, 61(10), 1062-1075.

Carroll, B. A., \& Ahuvia, A. C. (2006). Some antecedents and outcomes of brand love. Marketing Letters, 17(2), 79-89.

Goleman, D., \& Sutherland, S. (1996). Emotional Intelligence: Why it can matter more than IQ. Nature, 379(6560), 34-34.

Goleman, D. (2006). Emotional intelligence: Why it can matter more than IQ. Random House Digital, Inc.

Hwang, J., \& Kandampully, J. (2012). The role of emotional aspects in younger consumer-brand relationships. Journal of Product \& Brand Management, 21(2), 98-108.

Mayer, J. D., Caruso, D. R., \& Salovey, P. (1999). Emotional intelligence meets traditional standards for an intelligence. Intelligence, 27(4), 267-298.

Keller, K.L. (2001). Building customer-based brand equity. Marketing Management, 10(2), 14-21.

Park, C.W., MacInnis, J.D., \& Priester, J. (2006). Brand attachment: constructs, consequences, and causes. Foundations and Trends in Marketing, 1(3), 191-230. 